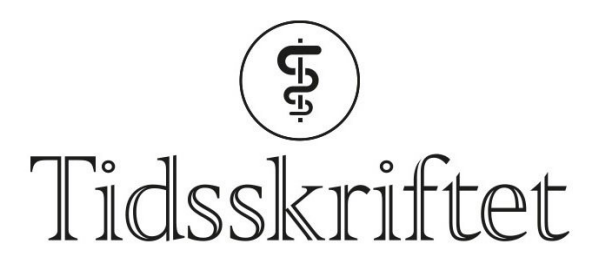

DEN NORSKE LEGEFORENING

\title{
Forside nr. 7/2019
}

FORSIDE

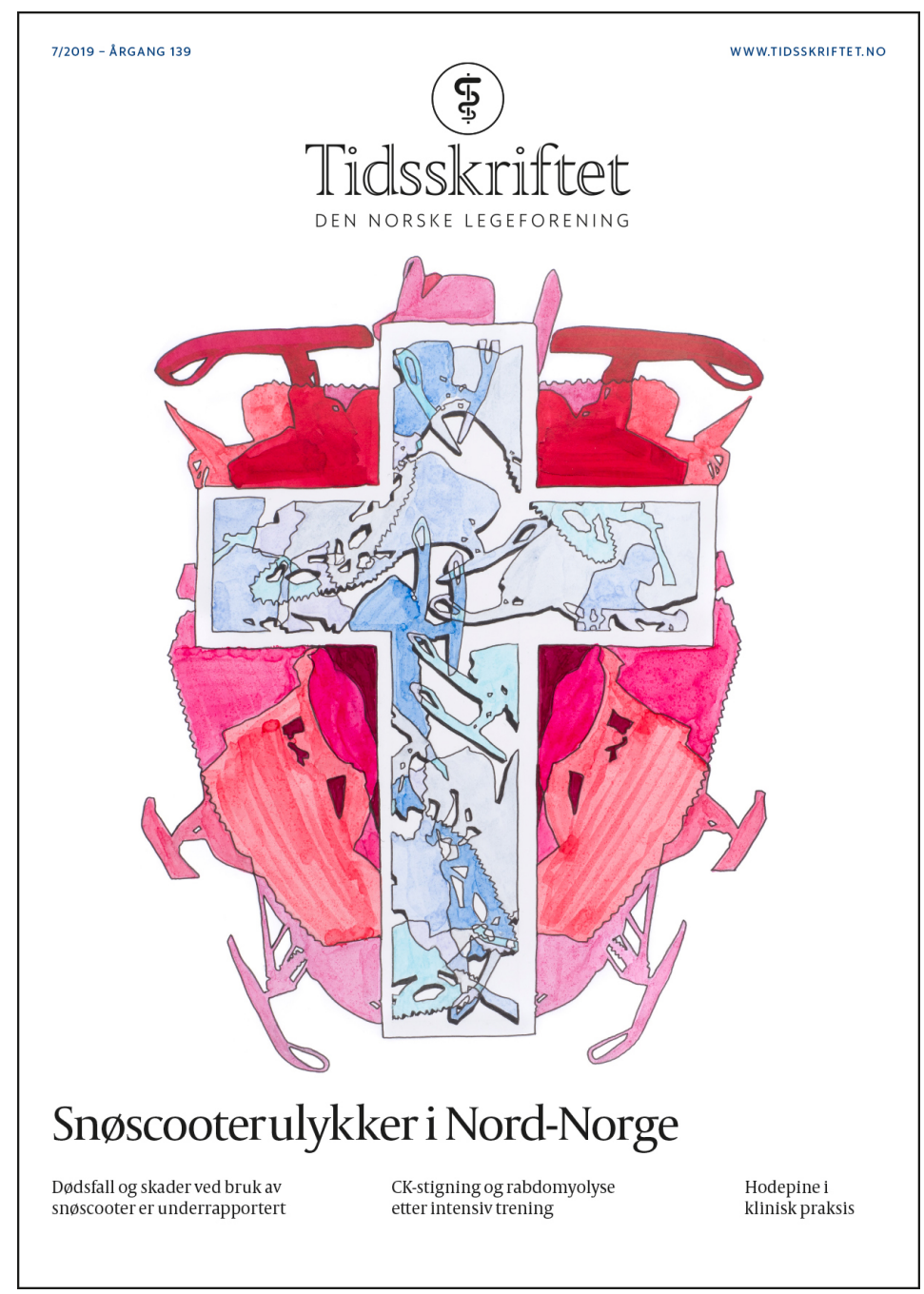

Illustrasjon (C) Anders Sunna

I denne utgaven av Tidsskriftet publiserer vi en artikkel om ulykker ved bruk av snøscooter og ATV i Nord-Norge. Det finnes ingen gode registre over slike ulykker, og det gjør forebyggende arbeid vanskelig. Finnmark har høyest forekomst av skaderelaterte dødsfall i Norge: jo fler snøscootere, jo fler dødsfall og skader. Bruk av snøscooter og terrengkjøretøy er viktig for samer som driver med reindrift. Forebyggende tiltak må utvikles med utgangspunkt i den samiske befolkningens kunnskap og behov. Det er mangel på urfolks perspektiver i norsk medisin, og Tidsskriftet har publisert få studier om samenes helsebehov. Samisk legeforening jobber nå for å sikre et samisk spesialisthelsetilbud som ivaretar den samiske befolkningens særegne situasjon, språk og kulturelle kontekst. Det er 
et arbeid som vi støtter. Vi har derfor invitert Anders Sunna til å illustrere forsiden til denne utgaven av Tidsskriftet. Han er kjent for å jobbe med politiske tema knyttet til samenes historie og situasjon i sin kunst. Du kan se mer av Sunnas kunst på hans nettside: anderssunna.com

Publisert: 8. april 2019. Tidsskr Nor Legeforen. DOI: 10.4045/tidsskr.19.07.02

(C) Tidsskrift for Den norske legeforening 2020. Lastet ned fra tidsskriftet.no 